\title{
A new species of Nitocra Boeck, I 865 (Harpacticoida, Ameiridae, Ameirinae) from South Africa, with notes on its ecology and remarks on the status of Nitocra sewelli husmanni Kunz, 1976
}

\author{
Samuel Gómez ${ }^{1, \dagger}$, Nicola K. Carrasco ${ }^{2, \ddagger}$, Francisco Neptalí Morales-Serna ${ }^{3, \S}$ \\ I Instituto de Ciencias del Mar y Limnología, Unidad Académica Mazatlán; Joel Montes Camarena s/n, \\ 82040, Mazatlán, Sinaloa, México 2 School of Life Sciences, University of KwaZulu-Natal, Westville Campus, \\ P. Bag. X54001, Durban 4000, South Africa 3 Departamento de Zoologia, Instituto de Biologia, Universidad \\ Nacional Autónoma de México, Avenida Universidad 3000; Ciudad Universitaria; C.P. 04510, Mexico, D.F. \\ † urn:lsid:zoobank.org:author:7BBFAB07-962F-4D10-9BE0-87B936993FBD \\ ¥ urn:lsid:zoobank.org:author:C24BB634-786D-4554-A33F-C8F1988A2FD8 \\ § urn:lsid:zoobank.org:author:293BFFE1-823A-4AB7-934D-3D223CBB8B23 \\ Corresponding author: Samuel Gómez (samuelgomez@ola.icmyl.unam.mx)
}

Academic editor: Danielle Defaye | Received 7 January 2012 | Accepted 26 July 2012 | Published 20 November 2012

urn:lsid:zoobank.org:pub:7C55FA7D-0D8A-43E3-94D7-E9167084A39C

Citation: Gómez S, Carrasco NK, Morales-Serna FN (2012) A new species of Nitocra Boeck, 1865 (Harpacticoida, Ameiridae, Ameirinae) from South Africa, with notes on its ecology and remarks on the status of Nitocra sewelli husmanni, Kunz 1976. ZooKeys 244: 33-58. doi: 10.3897/zookeys.244.2633

\begin{abstract}
A new species of the genus Nitocra Boeck, 1865, Nitocra taylori sp. n. is described from the St Lucia Estuary, Africa's largest estuarine lake. It is also suggested that Nitocra sewelli husmanni Kunz, 1976 and N. reducta fluviatilis Galhano, 1968 are granted full species rank as $N$. husmanni stat. n. Kunz, 1976 and N. fluviatilis stat. n. Galhano, 1968. Nitocra taylori sp. n. appears to be closely related to N. husmanni. Unfortunately, the original description of the micro-characters of the species lacks the detail needed to make reliable comparisons between species of the genus Nitocra. The main differences observed are the number of spinules along the posterior margin of the anal operculum, length ratio of the exopod and endopod of the first swimming leg, shape of the outer spine on the male third endopodal segment of the third swimming leg, number of segments of the male antennule, relative length of the setae on the male baseoendopod of the fifth leg, shape of the male exopod of the fifth leg, relative length of the two setae of the male sixth leg, and shape of the female baseoendopod of the fifth leg. The current distribution of $N$. taylori sp. n. is limited to the lake part of the estuary, an area which is most severely affected by the current freshwater deprivation crisis. During closed mouth conditions, these regions (South/North Lake
\end{abstract}

Copyright Samuel Gómez et al. This is an open access article distributed under the terms of the Creative Commons Attribution License 3.0 (CC-BY), which permits unrestricted use, distribution, and reproduction in any medium, provided the original author and source are credited. 
and False Bay) are characterized by low water levels, high salinities and high turbidity levels. This suggests that $N$. taylori sp. n. may favor these environmental conditions and the significant correlations found between the abundance of $N$. taylori sp. $\mathbf{n}$. and salinity and turbidity confirm this to a degree. Nitocra taylori sp. $\mathbf{n}$. individuals are also able to withstand a wide range of fluctuations. They were recorded at turbidities ranging from 2 to $102 \mathrm{NTU}$, temperatures from 20.9 to $34.8^{\circ} \mathrm{C}$ and salinity levels ranging from 9.81 to 53.7 psu. However, in the current state of the system, salinity and temperature levels in the northern regions frequently exceed this value. Continued freshwater deprivation may, therefore, further limit the distribution range of this species.

\section{Keywords}

Nitocra, taxonomy, ecology, St Lucia Estuary, South Africa

\section{Introduction}

During the course of routine quarterly monitoring surveys undertaken during the last six years in the St Lucia Estuary, South Africa, several specimens of an unidentified harpacticoid copepod were retrieved from zooplankton samples. The St Lucia Estuary is the largest estuarine lake in Africa and has high priority for conservation as it forms part of South Africa's first World Heritage Site - iSimangaliso (formerly Greater St Lucia) Wetland Park (Fielding et al. 1991, Cyrus and Vivier 2006) and is a Ramsar Wetland of International Importance (Begg 1978).

St Lucia characteristically experiences cyclical wet and dry phases, each lasting between four and ten years (Begg 1978). The below average rainfall which the area has received since 2002, coupled with a range of anthropogenic interventions undertaken during the last century, have resulted in the current drought cycle being one of the most severe the estuary has ever experienced (Whitfield and Taylor 2009). Low freshwater input and high evaporation rates have led to the persistence of a reversed salinity gradient, with hypersaline conditions in the upper reaches, i.e. False Bay and North/South lakes (Figure 1). The northern lakes are also extremely susceptible to desiccation. At the peak of the drought in 2005-2006, up to 70\% of the lake bed was dry (Whitfield and Taylor 2009) and water temperatures in the shallow regions at times reached $50^{\circ} \mathrm{C}$.

In light of the current crisis, research efforts have been directed at clarifying the biodiversity structure of the ecosystem and the effects of this stress on its functioning. A number of new and potentially endemic taxa have been identified recently from samples collected during routine monitoring surveys in the St Lucia Estuary (Daly et al. 2012, Todaro et al. 2011). High densities of an unidentified harpacticoid of the genus Nitocra, here described as $N$. taylori sp. n., were collected from South Lake and False Bay. The genus Nitocra belongs to the large and heterogenous family Ameiridae. Amerids inhabit a wide range of sediment types and occur in virtually all salinity regimes (Boxshall and Halsey 2004). The first record of $N$. taylori sp. n. in the St Lucia Estuary dates back to 2006, when low densities were collected from Charters Creek, which is situated on the western shore of South Lake. It is possible that this species was present in earlier assessments conducted by Grindley (1976), however, in these assessments, harpacticoid copepods were not identi- 


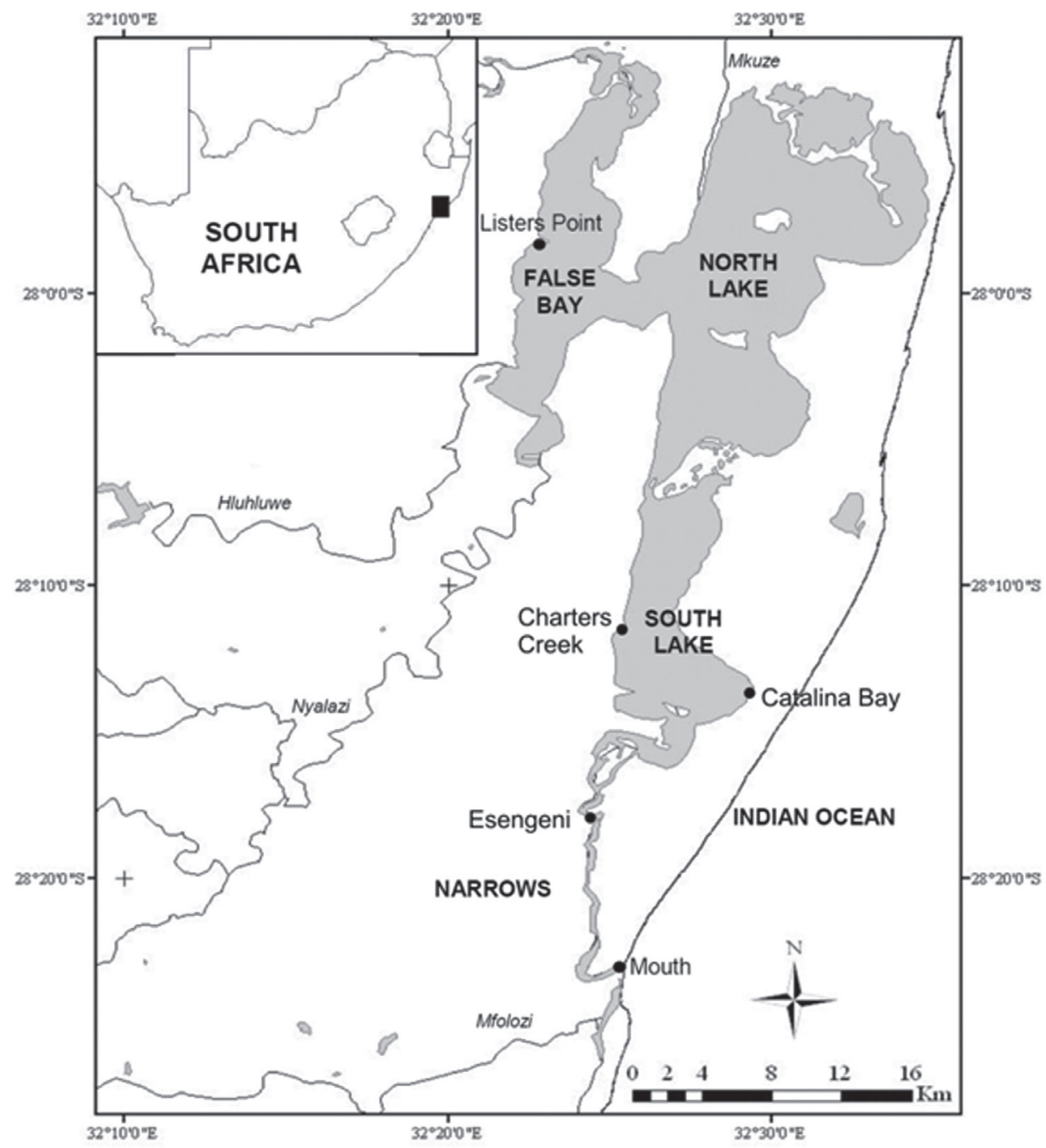

Figure I. St Lucia Estuary showing the sampling stations and geographic location within South Africa.

fied to species level. This study, therefore, aims to describe this species as well as document the basic characteristics of the habitat in which it occurs, in order to provide management with knowledge for the adequate protection of this potentially endemic species.

\section{Material and methods}

Quarterly surveys were undertaken at five representative stations within the St Lucia Estuary, from February 2006 through to May 2011. These stations included the Mouth, Esengeni, Catalina Bay, Charters Creek and Listers Point (Figure 1). The study period covered three different hydrological phases, viz. a closed-mouth phase (Febru- 
ary 2006 to February 2007), an open-mouth phase (March 2007 to August 2007), and a re-closed period (November 2007 to May 2011). Zooplankton together with physico-chemical data, were collected at each site on each sampling occasion.

\section{Physico-chemical variables}

Physico-chemical measurements were taken with a YSI 6920 water quality logger, fitted with temperature $\left({ }^{\circ} \mathrm{C}\right)$, depth $(\mathrm{m})$, conductivity $(\mathrm{mS} / \mathrm{cm})$, dissolved oxygen $(\mathrm{mg} . \mathrm{L}-$ $\left.{ }^{1}\right), \mathrm{pH}$ and turbidity (Nephelometric Turbidity Units or NTUs) probes.

\section{Zooplankton sampling}

Single daytime mesozooplankton samples were collected using an epibenthic sled (100 $\mu \mathrm{m}$ mesh). The sled was towed in the shallow waters near-shore at all stations, except at Esengeni, where a boat was used. The mouth of the net was semi-circular in shape (radius $=18.5 \mathrm{~cm}$ ) and was mounted on a sled that was towed just above the sediment surface. Sampling with this sled, therefore, allowed the suitable collection of epibenthic harpacticoids. In regions where water depth was too shallow, or when zooplankton was too dense for the sled to be used, $30 \mathrm{~L}$ of water was passed through a $100 \mu \mathrm{m}$ sieve. Samples were emptied into $500 \mathrm{~mL}$ bottles containing $4 \%$ phloxine-stained formaldehyde.

In the laboratory, samples were suspended in 0.5 to $5 \mathrm{~L}$ solutions, depending on the density of organisms. The main sample was then stirred vigorously so that all the organisms remained in a homogenous suspension. A $20 \mathrm{~mL}$ plastic vial attached to a metal rod was then used to withdraw three subsamples from mid-depth (Perissinotto and Wooldridge 1989, Carrasco et al. 2010). Individuals of $N$. taylori sp. n. within the samples were identified and counted with a Kyowa 129 SDZ dissecting microscope $(400 \mathrm{x})$ and density was then calculated as ind. $\mathrm{m}^{-3}$.

\section{Statistical analyses}

Univariate statistical analyses were conducted with SPSS version 19 for Windows, where a Pearson correlation was used to test for relationships between environmental variables and species abundance. This analysis was performed on log-transformed abundance data for all non-zero records.

\section{Species description}

A number of adult males and females were fixed in $4 \%$ formalin and preserved in $70 \%$ ethanol for taxonomic analyses and description. Observations and drawings were done 
at a magnification of $1000 \mathrm{x}$ from whole and dissected specimens mounted in lactophenol with a Leica compound microscope equipped with phase contrast and a drawing tube. The type material was deposited in the collection of the Instituto de Ciencias del Mar y Limnología, Unidad Académica Mazatlán (Mexico) (EMUCOP) and in the collection of the Iziko South African Museum, Cape Town (South Africa) (SAM). The terminology proposed by Huys and Boxshall (1991) for the general description was adopted. The relative length of the setae of the male and female P5 was calculated dividing the length of each seta by the total length of the longest element. Abbreviations used in the text and tables are: P1-P6, first to sixth swimming legs; EXP, exopod; ENP, endopod; P1(P2-P4)EXP(ENP)1(2,3) denotes the proximal (middle, distal) exopodal (endopodal) segment of P1, P2, P3 or P4; BENP, baseoendopod; ae, aesthetasc.

\section{Taxonomic account}

\section{Family Ameiridae Monard, 1927 \\ Subfamily Ameirinae Lang, 1944 \\ Genus Nitocra Boeck, 1865}

\section{Nitocra taylori sp. $\mathbf{n}$.}

urn:Isid:zoobank.org:act:AF4F4062-2DF8-41B5-9089-B62EECAB56B1

http://species-id.net/wiki/Nitocra_taylori

Figures 2-9

Type material. One female holotype (EMUCOP-080311-03) and one male allotype (EMUCOP-080311-06) preserved in alcohol, one female (EMUCOP-080311-04) and one male (EMUCOP-080311-05) dissected paratypes, and 15 adult females, 11 adult males, one CIII, three CIV and three CV paratypes preserved in alcohol (EMUCOP-080311-07) were deposited in the Copepoda collection of the Instituto de Ciencias del Mar y Limnología, Mazatlan Marine Biological Station; 26 additional paratypes (SAM-A45750) were deposited in the collection of the Iziko South African Museum; collected from Listers Point, St Lucia Estuary, South Africa; 8 March 2011; leg. N. K. Carrasco.

Type locality. Listers Point, False Bay, St Lucia Estuary, South Africa (27058'09.4"S, 32०22'48.11"E).

Etymology. The species is named after Dr Ricky H. Taylor, former Regional Ecologist at Ezemvelo KZN Wildlife, St Lucia Estuary, for his invaluable help provided to research and his lifetime efforts towards the conservation of the St Lucia Estuary. The specific epithet is a noun in the genitive singular.

Female. Habitus (Figure 2A) tapering posteriorly; total body length measured from tip of rostrum to posterior margin of caudal rami ranging from 460 to $685 \mu \mathrm{m}$ (mean, $537 \mu \mathrm{m} ; \mathrm{n}=11$; holotype, $525 \mu \mathrm{m}$ ). Rostrum (Figure 2A, B) defined at base, elongate, small, barely reaching distal margin of first antennulary segment, with pair of 


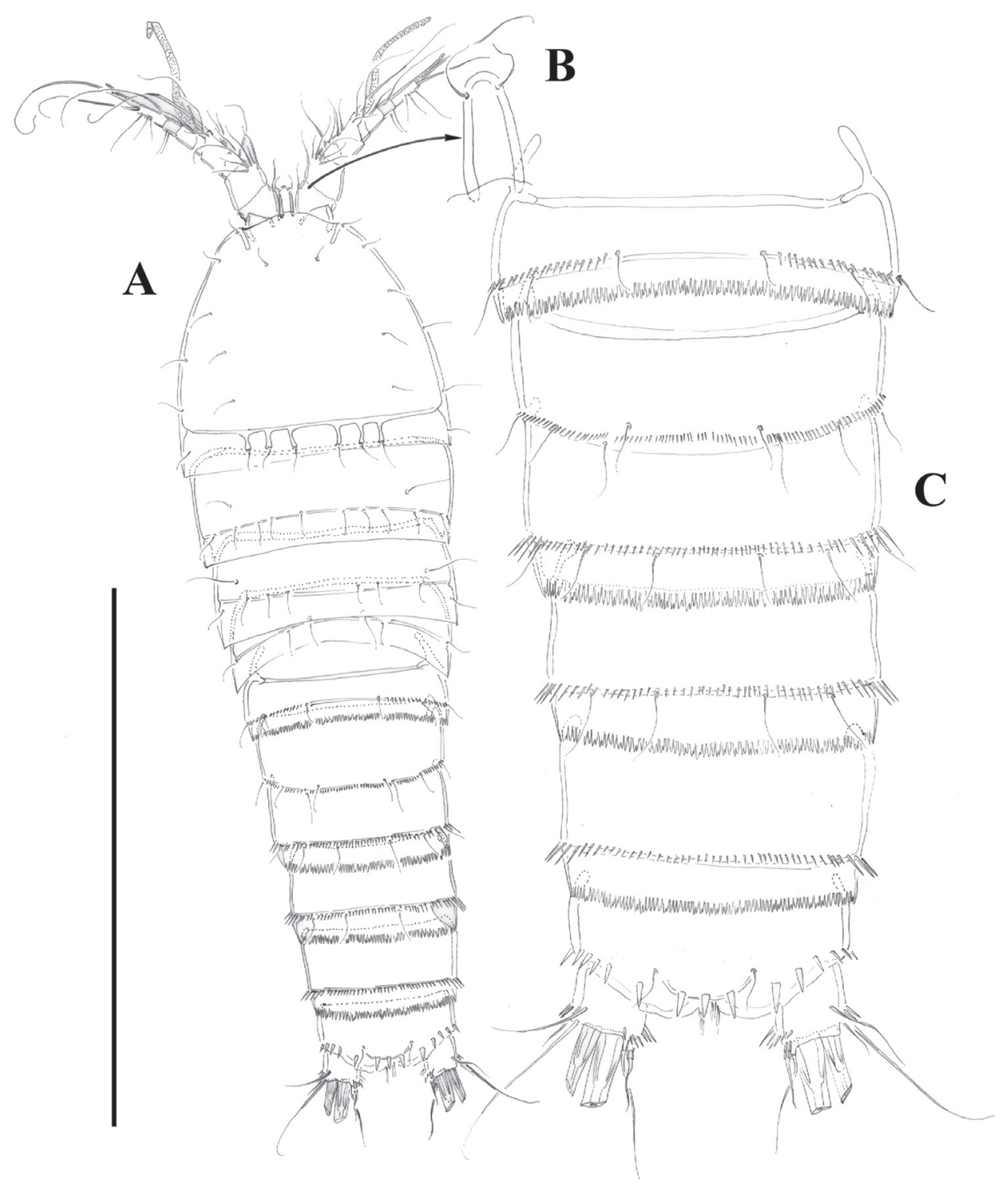

Figure 2. Nitocra taylori sp. n. Female. A habitus B rostrum, dorsal $\mathbf{C}$ urosome, dorsal. Scale bar: $\mathbf{A}=300 \mu \mathrm{m} ; \mathbf{B}=75 \mu \mathrm{m} ; \mathbf{C}=150 \mu \mathrm{m}$.

sensilla subapically. Dorsal surface of cephalic shield and free prosomites without spinular ornamentation, with plain caudal frill (Figure 2A). P5-bearing somite with medially interrupted row of minute spinules close to posterior margin dorsolaterally, with deeply serrate caudal frill (Figure 2A, C). Subcuticular rib of genital double-somite with dorsolateral row of small spinules indicating former division between second and third urosomites (Figure 2A, C), but completely fused ventrally (Figs 3B, 10F); third urosomite with comparatively stronger spinules close to posterior margin dorsally and 


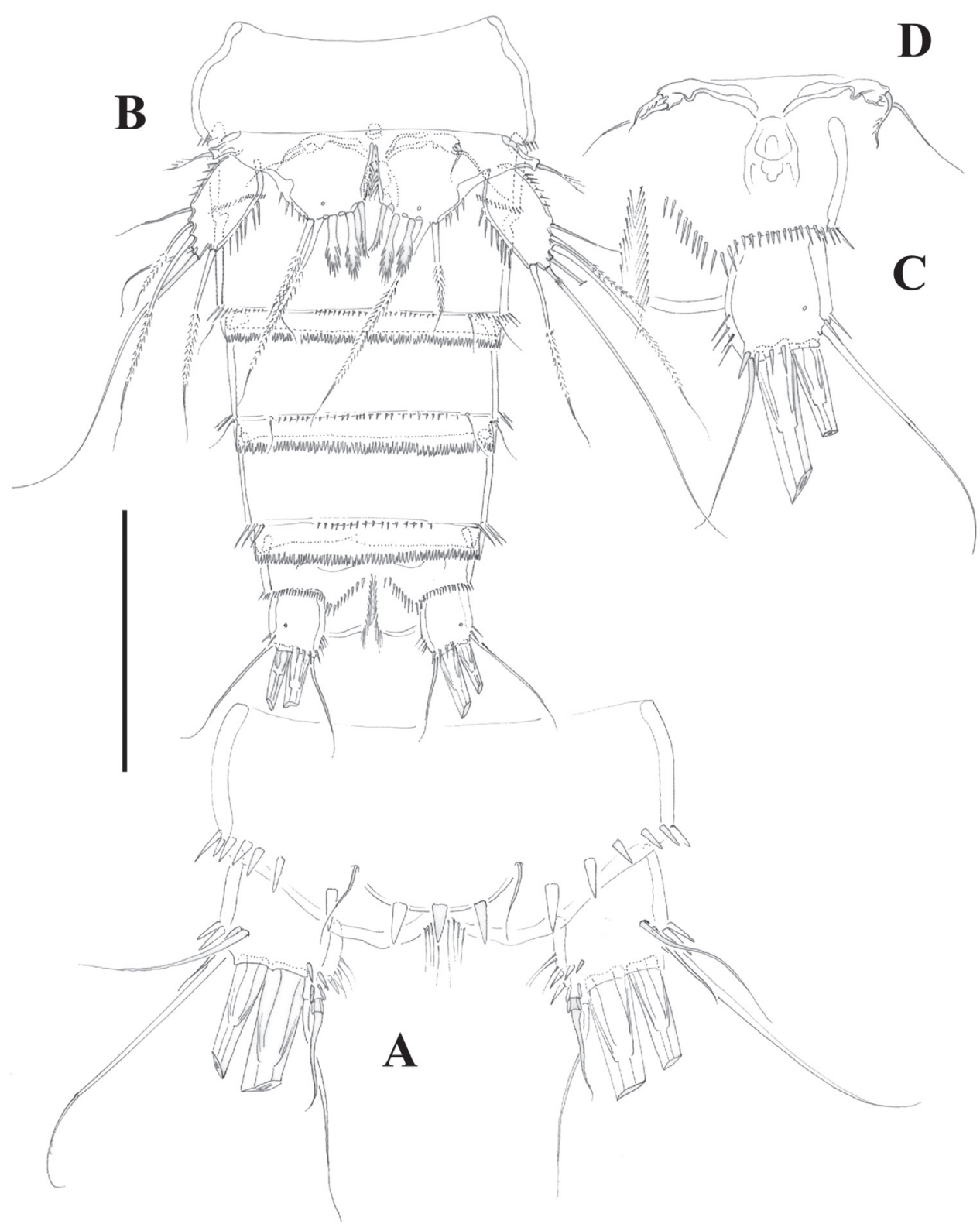

Figure 3. Nitocra taylori sp. n. Female. A anal somite and caudal rami, dorsal $\mathbf{B}$ urosome, ventral, showing P5 C left caudal ramus, ventral D P6 and genital complex. Scale bar: A=44 $\mu \mathrm{m} ; \mathbf{B}=100 \mu \mathrm{m}$; $\mathbf{C}=50 \mu \mathrm{m} ; \mathbf{D}=71 \mu \mathrm{m}$.

laterally, with median row of minute spinules ventrally, with deeply serrate caudal frill. Fourth and fifth urosomites as previous somite dorsally and ventrally, except for less and lack of sensilla in fourth and fifth urosomites, respectively. Anal somite somewhat shorter than previous somite, with strong spinules dorsally and laterally close to joint 
with caudal rami (Figs 2A, C, 3A), with comparatively smaller spinules ventrally (Figs $3 \mathrm{~B}, \mathrm{C}, 10 \mathrm{~F}$ ); rounded anal operculum with three strong spinules close to posterior margin, and flanked by pair of sensilla (Figs 2C, 3A). Caudal rami nearly as long as wide from dorsal view, but slightly longer than wide ventrally (Figs 2C, 3A, B, C, 10B), with seven setae as follows: seta I small, nearly as long as caudal ramus; seta II dorsal to seta I, about twice as long as the latter; seta III about twice as long as seta II, arising close to outer distal corner; setae IV and V well developed, the latter longest; seta VI arising from inner distal corner, slightly shorter than seta III; seta VII biarticulated, rather short, arising close to base of seta VI at inner distal corner.

Antennule (Figure 5A) eight-segmented, surface of segments smooth except for spinular row on first segment. Armature formula as follows: 1-(1), 2-(9), 3-(8), 4-(3 $+[1+\mathrm{ae}]), 5-(2), 6-(3) ; 7-(4) ; 8-(5+$ acrothek). Fourth segment with one outer spinule. Acrothek consisting of two setae and one aesthetasc fused at their base.

Antenna (Figure 4A) with small coxa. Allobasis without abexopodal setae, and ornamented with one long spinule and a short row of minute spinules proximally. Free endopodal segment with inner spinules proximally and subdistally, with two lateral inner spines and one slender seta, and four single geniculate setae and one geniculate element fused basally to pinnate seta. Exopod one-segmented; with few spinules, and three setae (two pinnate spine like elements and one bipinnate seta).

Mandible (Figure 4B) robust; gnathobase with bi- and multicuspidate teeth, and one lateral seta. Mandibular palp two-segmented; first segment (basis) with some spinules and one seta; second segment (endopod) with one lateral and four apical setae.

Maxillule (Figure 4C). Arthrite of praecoxa with few spinules, with two surface setae, and three bare spines and two serrate/multicuspidate elements. Coxa with two elements. Basis seemingly with four setae; exopod vestigial represented by one seta; endopod two-segmented, first segment without any setae, second segment with two setae.

Maxilla (Figure 6A). Syncoxa with minute outer spinules; with one endite bearing three setae. Allobasis drawn into strong claw with one accompanying strong element. Endopod one-segmented, with two setae.

Maxilliped (Figure 6B) subchelate. Syncoxa with spinular rows and with one seta on inner distal corner. Basis unarmed, with longitudinal row of spinules, with some outer spinules distally. Endopod drawn into long and slender claw with one accompanying small seta.

P1 (Figure 4D, E). Intercoxal sclerite without spinular ornamentation; distal margin convex. Basis with inner and outer flagellate spine; with strong spinules at base of inner spine, between rami and at base of exopod. Exopod and endopod three-segmented; EXP1 without inner seta, EXP2 with plumose inner seta; EXP3 with one outer proximal bipinnate spine, two outer naked spines and two geniculate elements. Endopod three-segmented; slightly beyond EXP; first segment slightly shorter that second and third segments combined, reaching insertion level of inner seta of EXP2; first segment with inner seta ornamented medially with setules and with spinules along outer margin distally; second segment with plumose inner seta; third segment with one inner plumose seta apically, one median geniculate element, and one apical outer spine. Armature formula as below. 


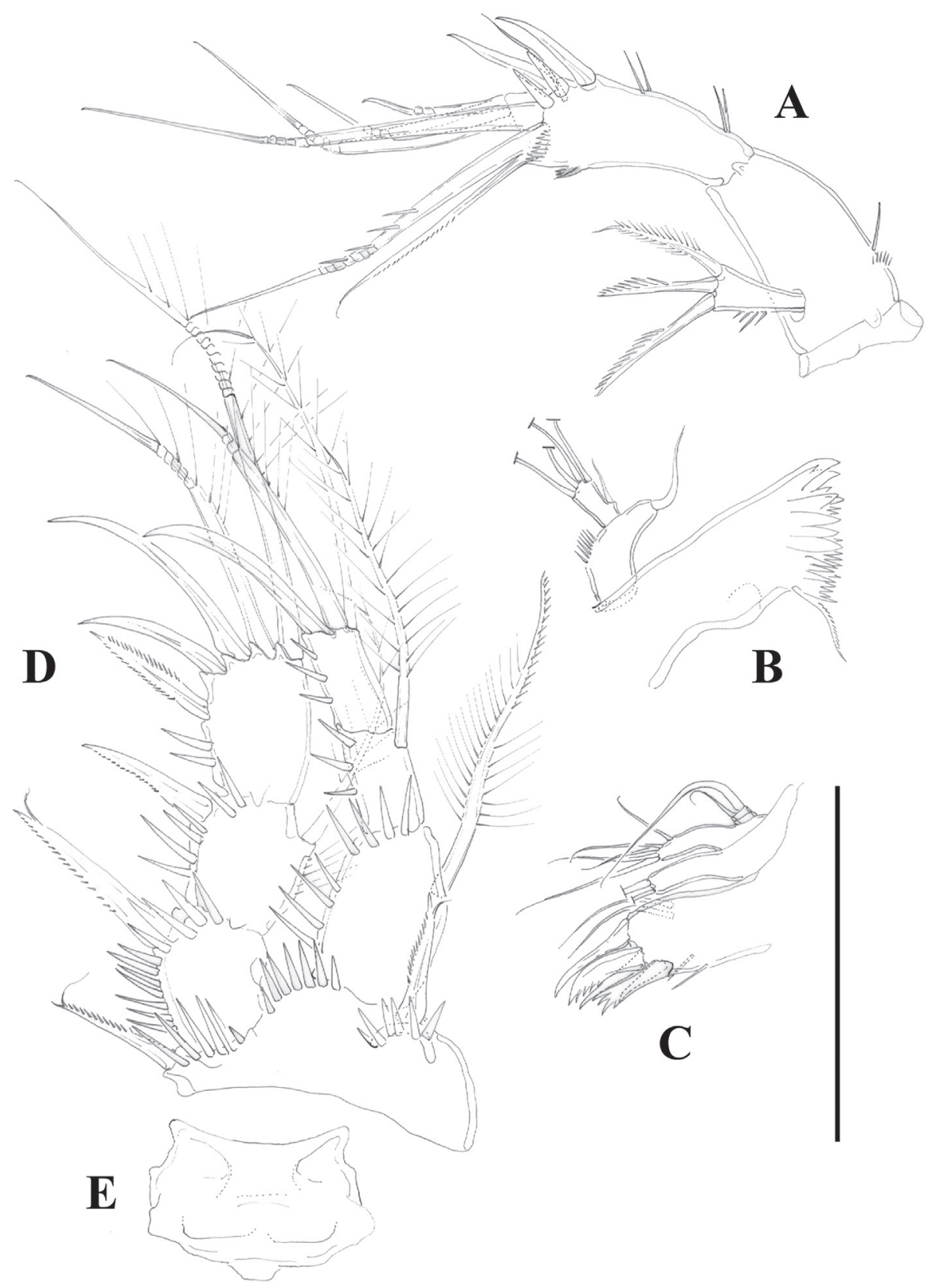

Figure 4. Nitocra taylori sp. n. Female. A antenna $\mathbf{B}$ mandible $\mathbf{C}$ maxillule D P1, anterior $\mathbf{E}$ intercoxal sclerite of P1, anterior. Scale bar: A-E $=50 \mu \mathrm{m}$.

P2 (Figure 5B). Intercoxal sclerite with transverse spinular row distally on both lobes. Praecoxa with spinules close to joint with coxa. The latter with long outer setules and minute spinules close to outer and inner distal corner, respectively. Basis 


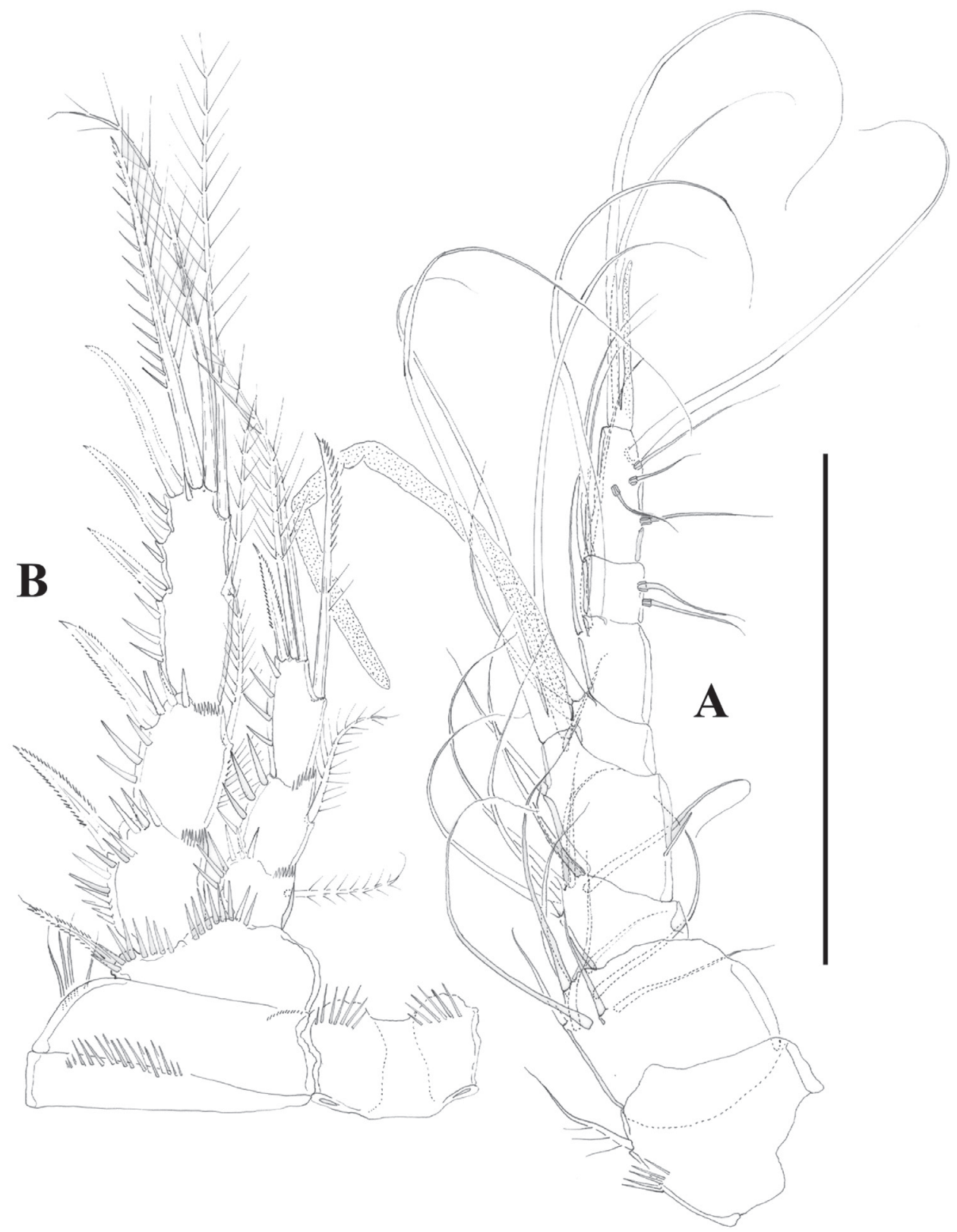

Figure 5. Nitocra taylori sp. n. Female. A antennule B P2, anterior. Scale bar: A=70 $\mu \mathrm{m} ; \mathbf{B}=100 \mu \mathrm{m}$.

with outer spine; with strong spinules between rami and at base of EXP. Exopod three-segmented; first segment without setae, second segment with plumose inner seta; third segment with three outer bipinnate spines, one outer apical seta ornamented with strong spinules and setules along outer and inner margin, respectively, one inner apical plumose seta and one inner plumose seta. Endopod three-segmented, reaching 


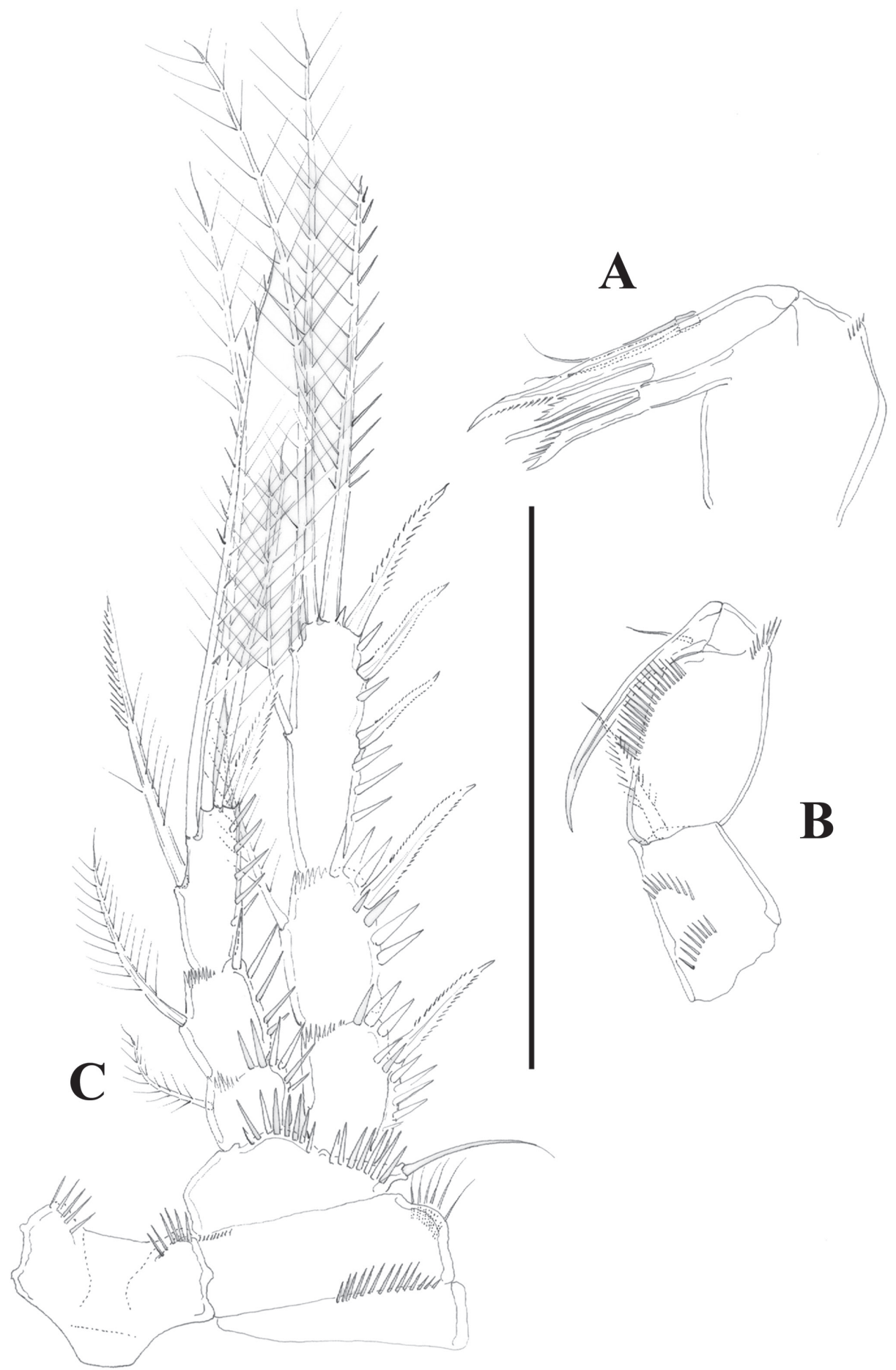

Figure 6. Nitocra taylori sp. n. Female. A maxilla B maxilliped C P3, anterior. Scale bar: A, B=70 $\mu$ m; $\mathrm{C}=100 \mu \mathrm{m}$. 
proximal fourth of EXP3; first and second segments with inner plumose and short seta; third segment with one strong inner seta ornamented with few setules medially and with spinules along outer margin distally, two apical plumose setae and one outer bipinnate spine. Armature formula as below.

P3 (Figure 6C). Intercoxal sclerite, praecoxa and coxa as in P2. Basis as in P2 except for outer seta-like element in P3. Exopod as in P2. Endopod as in P2 except for additional inner element in P3ENP3 ornamented with setules proximally and with spinules along outer margin distally; reaching proximal third of EXP3.

P4 (Figure 7A). Intercoxal sclerite without spinules. Praecoxa (not shown), coxa and basis as in P3. Exopod as in P3 except for comparatively stronger inner distal seta of P4EXP3 ornamented with outer and inner spinules, and for outer apical seta ornamented with inner setules and outer spinules. Endopod as in P3, except for bipinnate inner proximal seta on P4ENP3; slightly beyond EXP2.

P5 (Figure 7B). Both legs separated. Exopod and baseoendopod not fused. Exopod ovate; with inner and outer spinules; with six elements; relative length of the setae from inner to outer element as follows: $0.73,1,0.38,0.69,0.38,0.25$. Endopodal lobe with five setae/spines; relative length of the setae from inner to outer element as follows: $0.30,0.31 ; 0.30,1,0.52$; with inner and outer spinules.

Armature formula of female P1-P5 as follows:

\begin{tabular}{c|c|c|c|c|c}
\hline & P1 & P2 & P3 & P4 & P5 \\
\hline EXP & I-0;I-1;III,2,0 & I-0;I-1;III,2,2 & I-0;I-1;III,2,2 & I-0;I-1;III,2,2 & 6 \\
\hline ENP & $0-1 ; 0-1 ; \mathrm{I}, 2,0$ & $0-1 ; 0-1 ; \mathrm{I}, 2,1$ & $0-1 ; 0-1 ; \mathrm{I}, 2,2$ & $0-1 ; 0-1 ; \mathrm{I}, 2,2$ & 5 \\
\hline
\end{tabular}

P6 (Figure 3D) represented by median plate in anterior half of second urosomite (first genital somite); each vestigial leg represented by one outer short and one inner long seta.

Male. Habitus (not shown) as in female, except for distinct second and third urosomites; total body length measured from tip of rostrum to posterior margin of caudal rami ranging from 385 to $520 \mu \mathrm{m}$ (mean, $437 \mu \mathrm{m} ; \mathrm{n}=7$; allotype, $490 \mu \mathrm{m}$ ). Ventral spinular ornamentation of third-sixth urosomites coarser and stronger than in female (Figs 8, 10D). Caudal rami (Figs 8, 10D) as in female.

Sexual dimorphism expressed in the antennule, P1Basis, P3ENP, P5 and P6.

Antennule (Figure 9A) haplocer, nine-segmented; armature formula difficult to define, but most probably as follows: 1-(1), 2-(11), 3-(8), 4-(1), 5-(14+[1+ae]), 6-(1), 7-(2); 8-(1); 9-(9+acrothek); fifth, sixth and seventh (Figure 9B) and eight (Figure 9C) segments with modified setae and blunt spines/processes. Acrothek consisting of two setae and one aesthetasc basally fused.

Antenna (Figure 10E), mandible, maxillule, maxilla and maxilliped (not shown) as in female.

P1-P4 as in female, except for sexually dimorphic male P1 Basis (Figs 9D, 10A) and P3ENP (Figure 9E). The former with modified inner spine. The latter three-segmented; first and second segment as in female; third segment with outer longitudinal row of small spinules and armed with five setae/spines. 


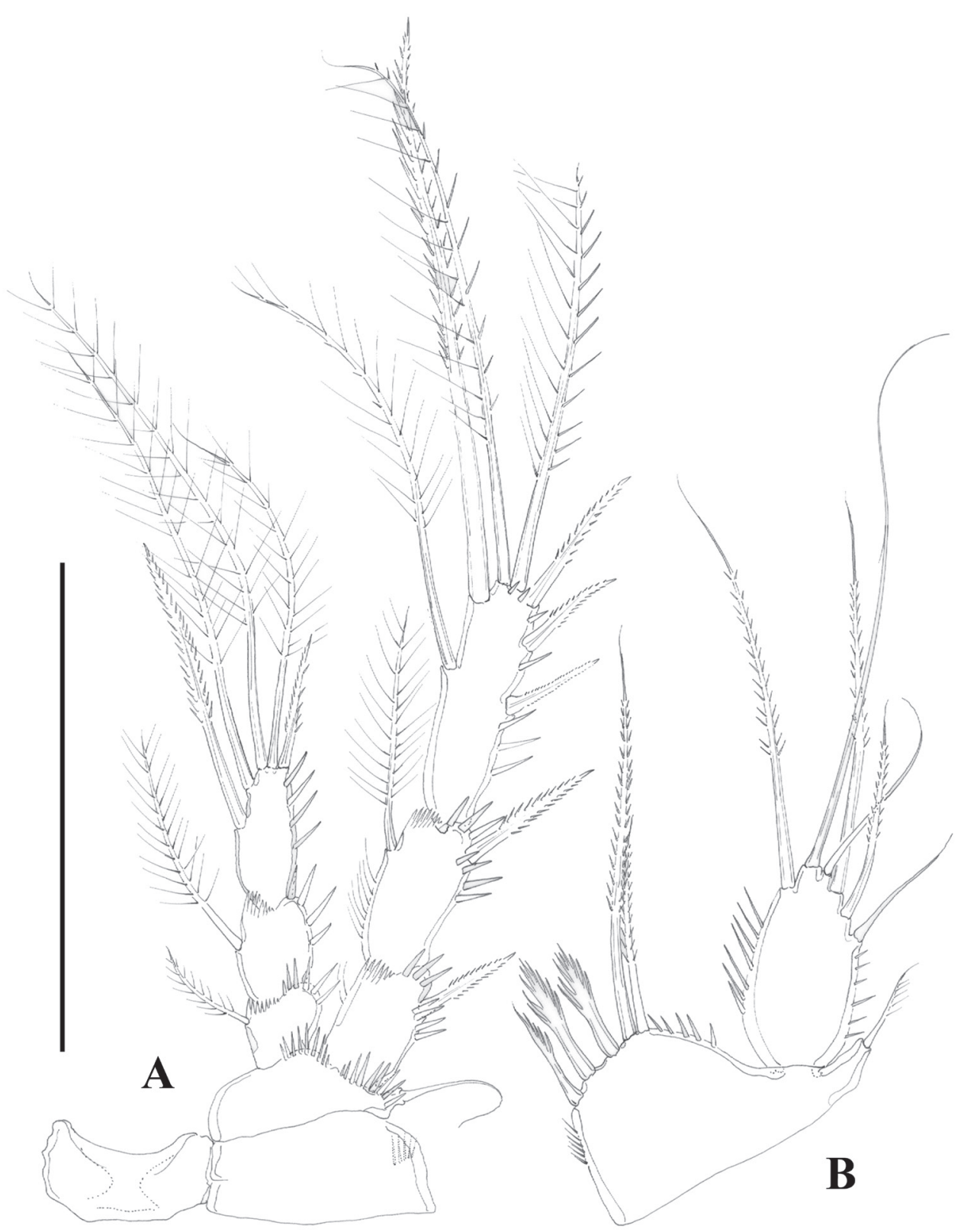

Figure 7. Nitocra taylori sp. n. Female. A P4, anterior B P5, anterior. Scale bar: A, B=100 $\mu \mathrm{m}$.

P5 (Figs 9F, 10C). Both legs fused medially. Exopod and baseoendopod separated. The former ovate, with six setae, relative length of elements from inner to outer margin as follows: $0.47,0.35,1.0,0.44,0.17,0.39$. Baseoendopodal lobe poorly developed, with three elements; relative length of elements from inner to outer margin as follows: 1.0, 0.79, 0.67. 


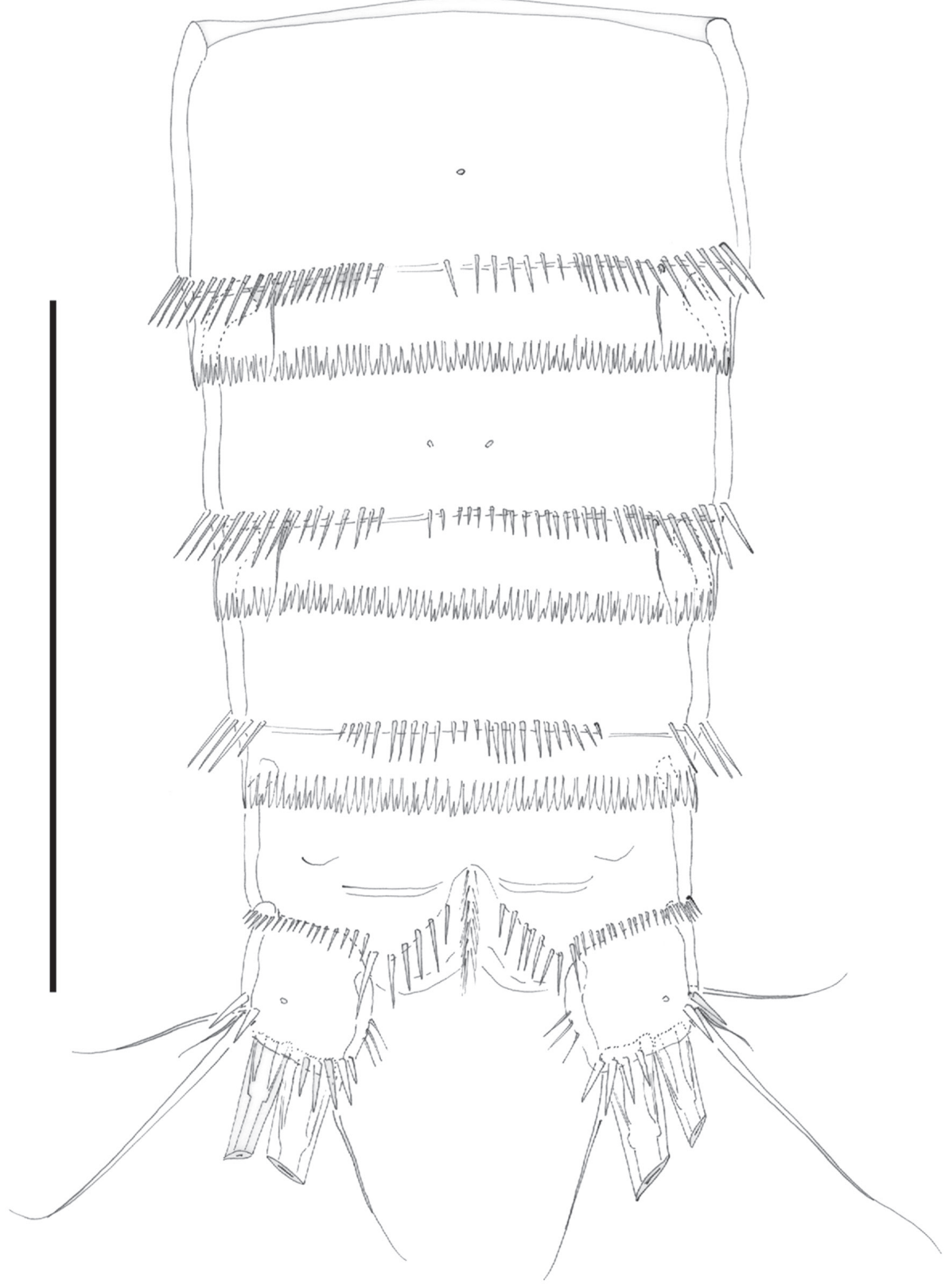

Figure 8. Nitocra taylori sp. n. Male. Urosome, ventral (P5- and P6-bearing somites omitted). Scale bar: $100 \mu \mathrm{m}$.

P6 (Figs 9G, 10C) represented by two setae situated rather laterally, outer seta smaller than inner element.

Ecology. Habitat characteristics. During closed-mouth conditions, the St Lucia Estuary was characterised by a reversed salinity gradient, with salinities ranging from 


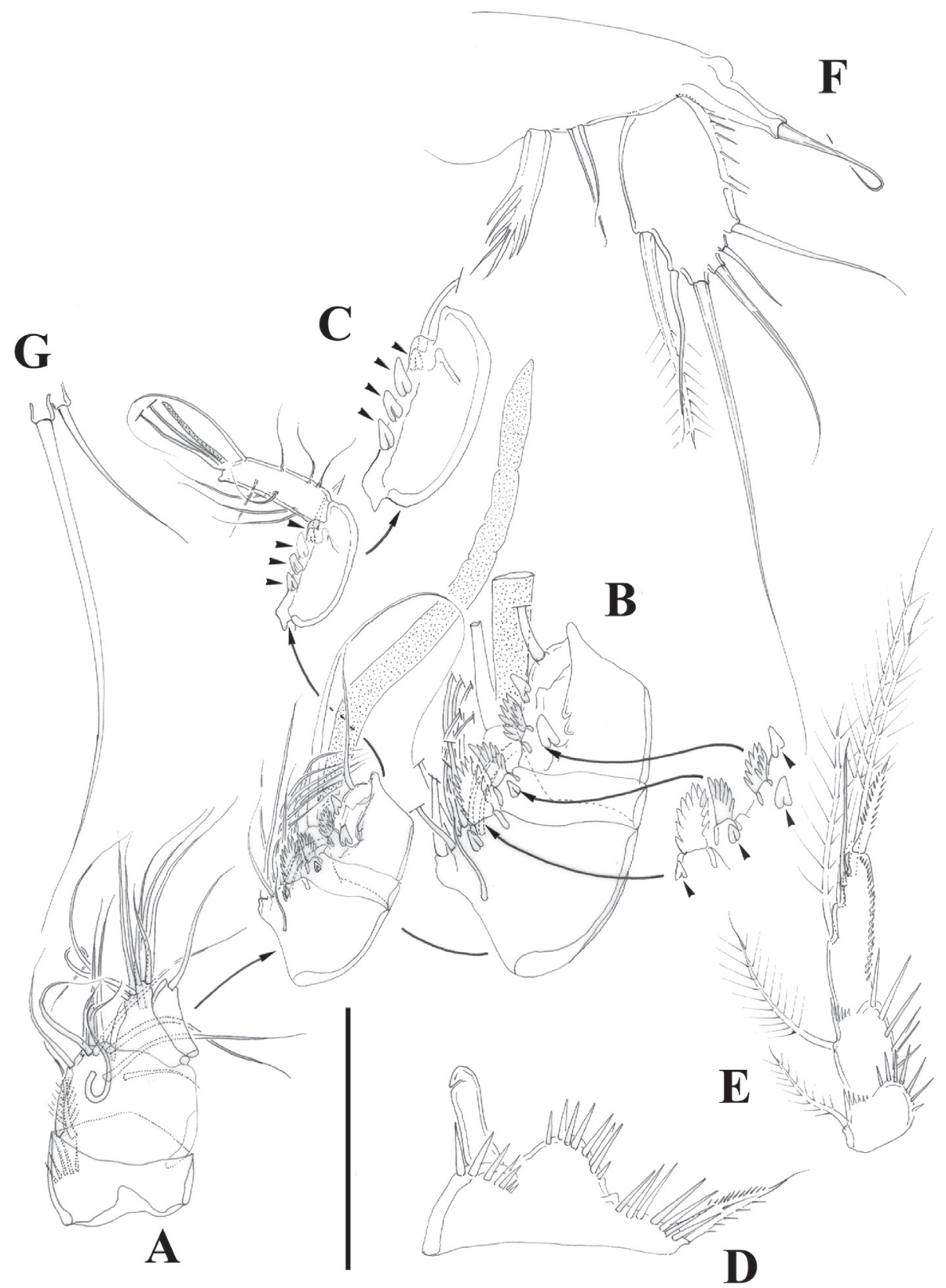

Figure 9. Nitocra taylori sp. n. Male. A antennule B fifth, sixth and seventh segments of the antennule, showing modified setae and blunt processes $\mathbf{C}$ eight segment of the antennule $\mathbf{D}$ P1 basis, anterior E P3ENP F P5, anterior G P6, anterior. Scale bar: A, E=50 $\mu \mathrm{m} ; \mathbf{B}, \mathbf{C}=67 \mu \mathrm{m} ; \mathbf{D}, \mathbf{F}, \mathbf{G}=35 \mu \mathrm{m}$.

near freshwater conditions at the Mouth and Narrows, to up to 200 psu at times in the northern regions of the lake (Table 1). Salinity levels were also more variable in the lakes than in the Mouth and Narrows region. Throughout the study period, salinity 


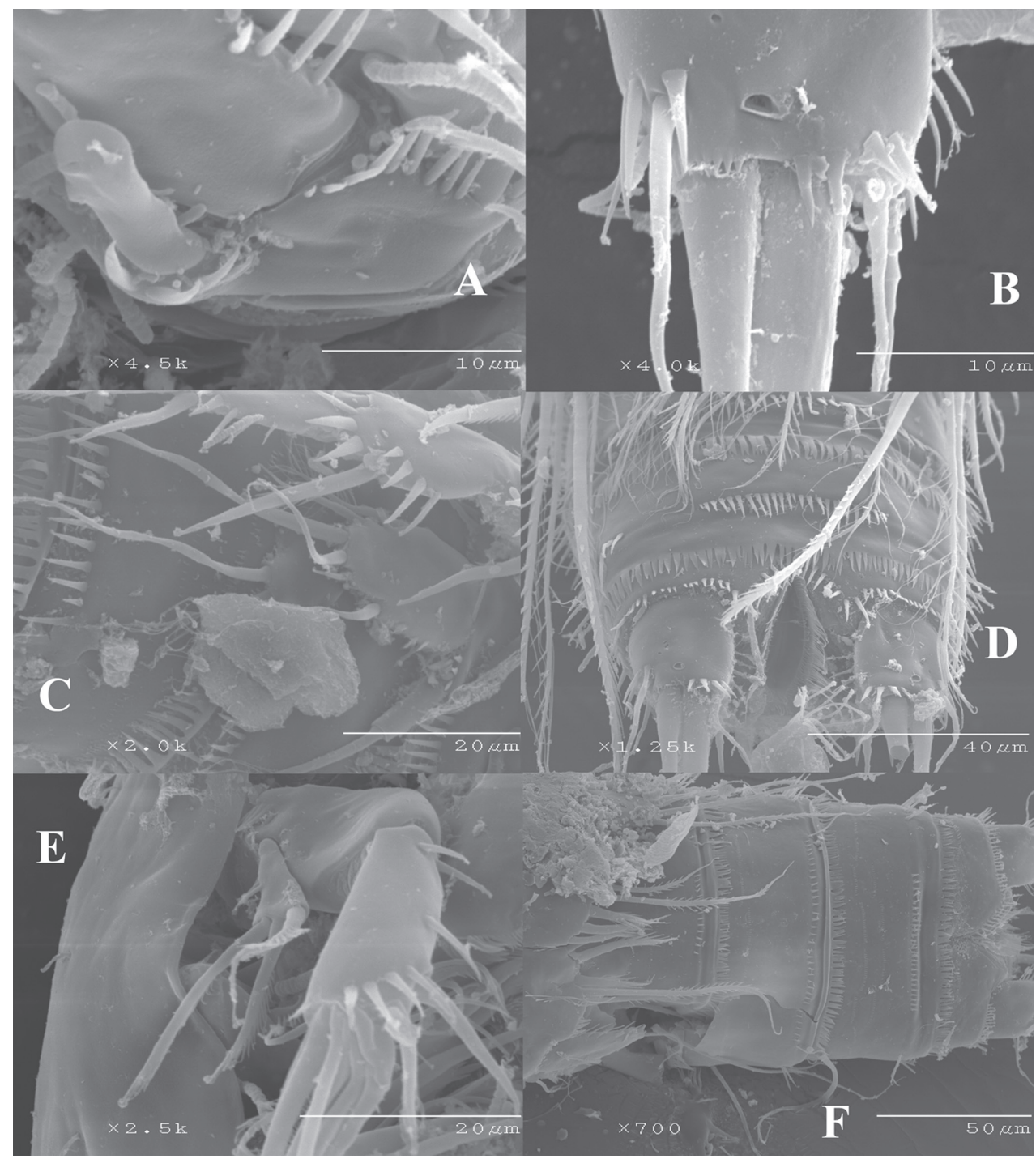

Figure 10. Nitocra taylori sp. n. SEM photographs $\mathbf{A}$ male P1 showing inner modified spine of basis B female caudal rami $\mathbf{C}$ male P5 exopod and P6 D posterior part of male urosome including caudal rami $\mathbf{E}$ male antenna $\mathbf{F}$ anterior part of female urosome.

levels at the Mouth ranged from 3.2 to 37.6 psu, while at Listers Point they ranged from 18.3 to 216 psu. During closed-mouth conditions, water depth was also generally highest at the Mouth and Esengeni and shallower $(\sim 0.2 \mathrm{~m})$ in the lakes (Table 1$)$. High wind action, coupled with the fine sandy substratum in the lakes, also resulted in higher turbidity levels experienced here relative to the Mouth and Narrows. Listers Point and Charters Creek generally experienced the highest turbidities, while levels at the Mouth were usually at least one order of magnitude lower (Table 1). During open-mouth conditions, there was little disparity between sites in terms of the physico- 


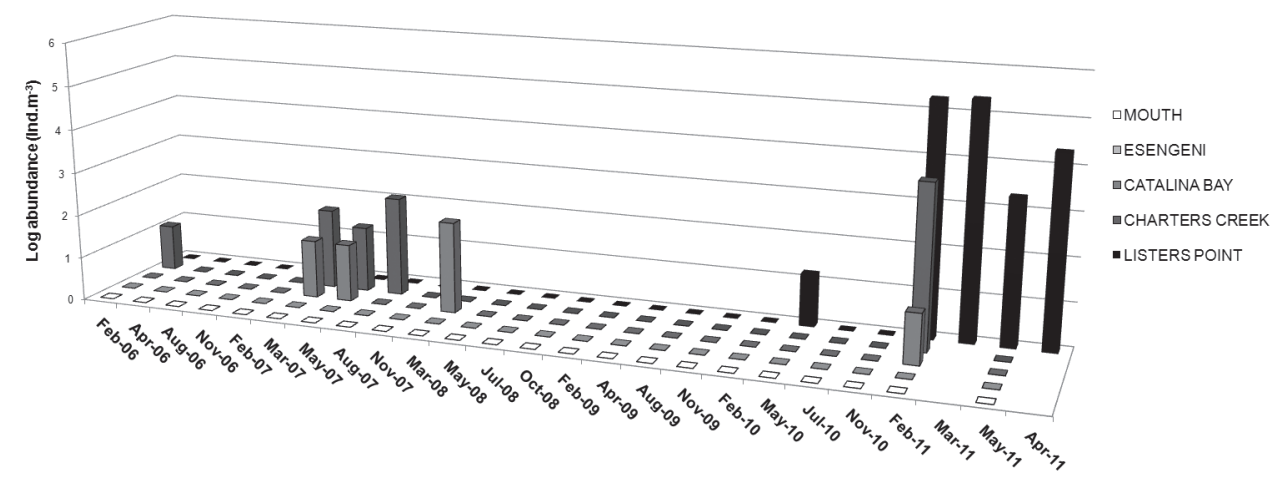

Figure II. Abundance of Nitocra taylori sp. n. (ind. $\mathrm{m}^{-3}$ ) in the St Lucia Estuary from February 2006April 2011.

Table I. Physicochemical variables measured at each station during the different mouth phases (mean \pm SE). NTU: Nephelometric Turbidity Units; DO: dissolved oxygen.

\begin{tabular}{c|c|c|c|c|c|c|c}
\hline $\begin{array}{c}\text { Mouth } \\
\text { state }\end{array}$ & Station & $\begin{array}{c}\text { Depth } \\
(\mathbf{m})\end{array}$ & $\begin{array}{c}\text { DO } \\
\left(\mathbf{m g . L ^ { - 1 }}\right)\end{array}$ & $\mathbf{p H}$ & $\begin{array}{c}\text { Salinity } \\
(\mathbf{p s u})\end{array}$ & $\begin{array}{c}\text { Temperature } \\
\left(\mathbf{o}^{\mathbf{C}}\right)\end{array}$ & $\begin{array}{c}\text { Turbidity } \\
(\mathbf{N T U})\end{array}$ \\
\hline Closed & Mouth & $2.05 \pm 0.52$ & $7.9 \pm 0.52$ & $8.02 \pm 0.37$ & $12.8 \pm 1.67$ & $26.5 \pm 2.32$ & $9.36 \pm 5.82$ \\
\hline & Esengeni & $1.38 \pm 0.12$ & $7.75 \pm 1.13$ & $8.37 \pm 0.17$ & $6.45 \pm 1.52$ & $24.5 \pm 1.98$ & $28.7 \pm 3.76$ \\
\hline & Catalina Bay & $0.15 \pm 0.04$ & $9.06 \pm 0.91$ & $8.52 \pm 0.14$ & $14.5 \pm 3.24$ & $24.8 \pm 2.58$ & $42.8 \pm 20.5$ \\
\hline & Charters Creek & $0.11 \pm 0.02$ & $8.38 \pm 1.04$ & $8.79 \pm 0.22$ & $24 \pm 4.48$ & $29.2 \pm 2.5$ & $33.2 \pm 11.0$ \\
\hline & Listers Point & $0.07 \pm 0.02$ & $4.96 \pm 1.52$ & $8.17 \pm 0.14$ & $43.9 \pm 21.58$ & $29.8 \pm 1.44$ & $49.6 \pm 12.7$ \\
\hline Open & Mouth & $0.75 \pm 0.35$ & $7.57 \pm 0.63$ & $8.08 \pm 0.14$ & $34.6 \pm 1.05$ & $23.1 \pm 1.6$ & $24.4 \pm 15.8$ \\
\hline & Esengeni & $1.51 \pm 0.21$ & $5.23 \pm 1.48$ & $8.25 \pm 0.07$ & $37.4 \pm 9.38$ & $20.3 \pm 2.98$ & $45.6 \pm 13.5$ \\
\hline & Catalina Bay & $0.33 \pm 0.18$ & $7.5 \pm 1.26$ & $7.99 \pm 0.38$ & $29.1 \pm 3.26$ & $23.7 \pm 3.4$ & $8.37 \pm 4.18$ \\
\hline & Charters Creek & $0.53 \pm 0.22$ & $7.82 \pm 1.52$ & $8.11 \pm 0.21$ & $29.6 \pm 3.1$ & $24.5 \pm 3.63$ & $13.4 \pm 5.96$ \\
\hline & Listers Point & $0.43 \pm 0.28$ & $6.91 \pm 0.91$ & $7.01 \pm 1.01$ & $35.1 \pm 4.25$ & $23.8 \pm 2.73$ & $32.8 \pm 17.7$ \\
\hline Re-closed & Mouth & $1.4 \pm 0.23$ & $6.85 \pm 1.02$ & $8.72 \pm 0.26$ & $15.3 \pm 2.44$ & $23.0 \pm 0.87$ & $20.0 \pm 3.68$ \\
\hline & Esengeni & $1.35 \pm 0.13$ & $7.51 \pm 0.58$ & $8.36 \pm 0.17$ & $9.39 \pm 2.19$ & $23.3 \pm 0.81$ & $60.3 \pm 12.6$ \\
\hline & Catalina Bay & $0.21 \pm 0.04$ & $7.01 \pm 1.18$ & $8.61 \pm 0.26$ & $37.5 \pm 5.25$ & $24.8 \pm 1.23$ & $50.6 \pm 10.5$ \\
\hline & Charters Creek & $0.2 \pm 0.04$ & $7.51 \pm 0.39$ & $8.65 \pm 0.19$ & $45.3 \pm 5.3$ & $26.3 \pm 1.06$ & $197 \pm 61.2$ \\
\hline & Listers Point & $0.31 \pm 0.05$ & $7.53 \pm 0.58$ & $8.53 \pm 0.19$ & $87.4 \pm 12.8$ & $25.6 \pm 1.73$ & $155 \pm 41.1$ \\
\hline
\end{tabular}

chemical parameters measured. Salinity was generally within the range of sea water $(-35 \mathrm{psu})$ across the estuarine lake and water levels in the lakes rose to approach the levels recorded at the Mouth and Narrows (Table 1).

Nitocra taylori sp. n. abundance and distribution. Occurrence of Nitocra taylori sp. n. through the study years has been irregular and the distribution has been limited to Catalina Bay and Charters Creek in South Lake and Listers Point in False Bay (Figs 1, 11). Nitocra taylori sp. n. was first recorded at Charters Creek in February 2006 in low densities $\left(10.4\right.$ ind. $\left.\mathrm{m}^{-3}\right)$, while maximum densities $\left(2.2 \times 10^{5}\right.$ ind. $\left.\mathrm{m}^{-3}\right)$ were recorded at Listers Point in March 2011. These high densities followed heavy dilution of hypersaline waters after high rainfall in early 2011. Densities remained high in this 

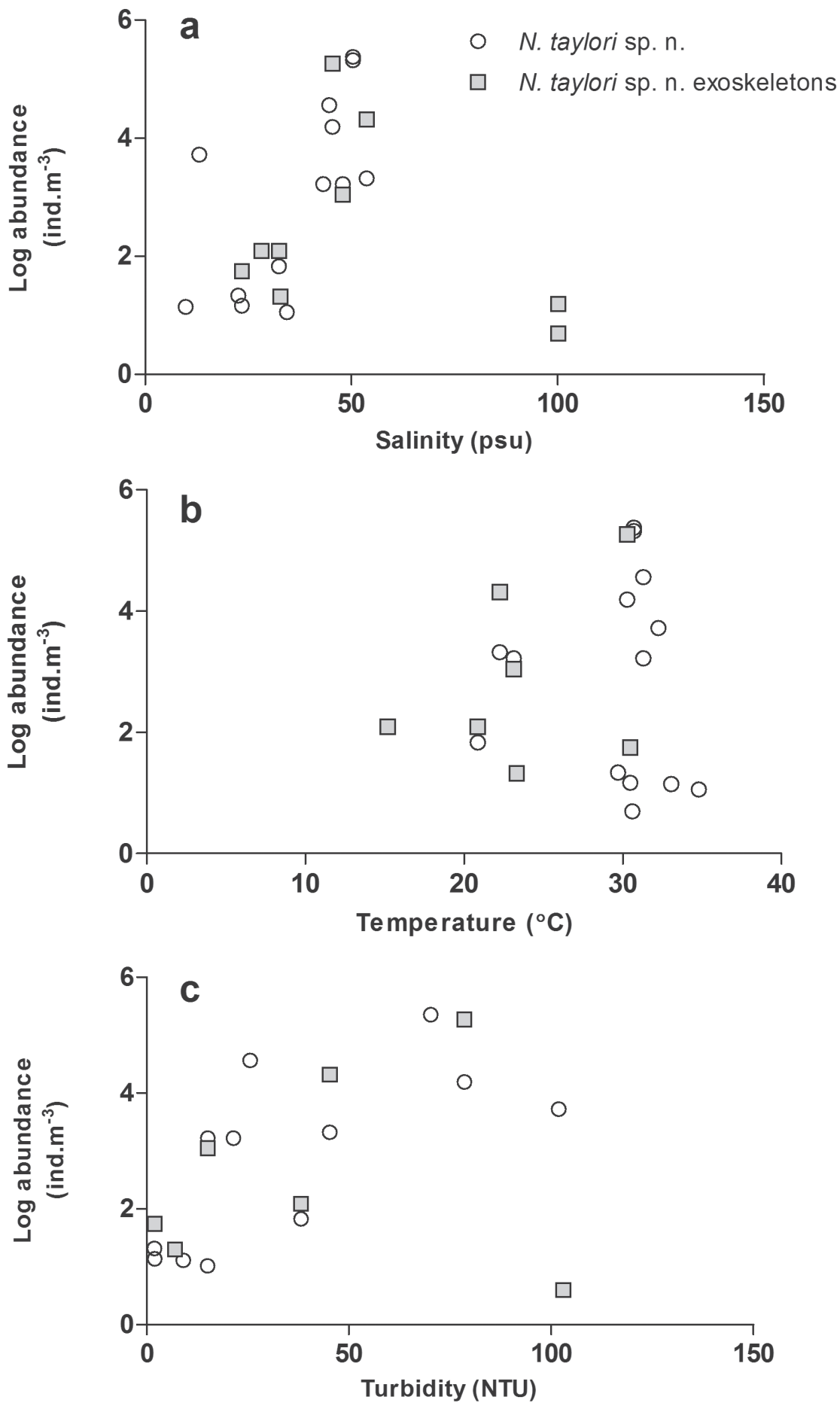

Figure 12. Abundance of Nitocra taylori sp. n. (alive and discarded exoskeletons) at different a salinity b temperature and c turbidity levels recorded in the St Lucia Estuary. 
region up until May 2011, after which salinities rose again above 53.7 psu and $N$. taylori sp. n. virtually disappeared. Correlation analysis found significant positive correlations between the abundance of $N$. taylori sp. $\mathrm{n}$. and salinity $(\mathrm{R}=0.621, \mathrm{p}<0.05$, $\mathrm{df}=12)$ and turbidity $(\mathrm{R}=0.681, \mathrm{p}<0.05, \mathrm{df}=12)$. Nitocra taylori $\mathrm{sp} . \mathrm{n}$. individuals were able to withstand a wide range of fluctuations. They were found at salinity levels ranging from 9.81 to 53.7 psu, turbidities ranging from 2 to 102 NTU and temperatures from 20.9 to $34.8{ }^{\circ} \mathrm{C}$ (Figure 12). In many instances specimens preserved in phloxine-stained formaldehyde did not take up the stain, but were rather completely transparent, resembling discarded exoskeletons. While these individuals were perfectly intact, it is unlikely that they were alive at the time of collection.

\section{Discussion}

\section{Taxonomic remarks}

The phylogenetic relationships of the species within the genus Nitocra are still obscure. At first glance, three species groups can be recognized based on the combination of the armature formula of the P1EXP2-3. The less speciose group, composed only by $N$. sewelli Gurney, 1927 and $N$. platypus bakeri Chappuis, 1930, exhibits one inner seta and four elements on the P1EXP2 and EXP3 respectively. This two-species group is followed by that lacking inner armature on the P1EXP2, but with five setae on P1EXP3 (N. reducta s. str. (Schäfer 1936), N. delaruei Soyer, 1974, and N. blochi Soyer, 1974). The rest of the species/subspecies belongs to the most diverse and seemingly primitive group characterized by the presence of one inner, and five elements on the P1EXP2 and EXP3, respectively.

The creation of species and subspecies of Harpacticoida might appear, sometimes, based on questionable grounds. This holds true, as evidenced by Wells and Rao (1987), for N. spinipes s. str. Boeck, 1865, N. spinipes orientalis Sewell, 1924 and $N$. spinipes armata Lang, 1965. The same applies at least for the subspecies of $N$. reducta and $N$. sewelli. As evidenced upon a brief analysis, the subspecific relationship of $N$. reducta s. str. and $N$. reducta fluviatilis Galhano, 1968 is questioned given the lack of inner armature in the former and the presence of an inner element in the latter. In our opinion, such difference is not evidence of the presence of a subspecies of $N$. reducta, but of a different species. Galhano (1968) herself noted also a remarkable difference in the armature formula of the female P5 baseoendopod (with four setae in Schäfer's $N$. reducta, but with five elements in Galhano's material). In the view of this evidence it is suggested to grant $N$. reducta fluviatilis Galhano, 1968 full species rank as N. Aluviatilis stat. n. Galhano, 1968, until the variability of these two species is properly assessed.

A similar case was observed for $N$. sewelli. Sewell (1924) described a new variety of the European Nitocra typica Boeck, 1865, Nitocra typica lacustris Sewell, 1924. However, the name lacustris was already occupied by Nitocra lacustris (Schmankevitch 
1875) and Gurney (1927) renamed and gave full species rank to Nitocra typica lacustris as Nitocra sewelli. He also presented a key to species of the genus in which he recognized 11 members as valid ( $N$. pusilla Sars, 1911, N. inuber (Schmankevitch, 1875), N. affinis, N. typica, N. dubia Sars, 1927, N. lacustris, N. fragilis Sars, 1905, N. wolterecki Brehm, 1909, N. spinipes, N. sewelli and N. platypus Daday, 1906. Lang (1948) recognized 16 valid species and 7 subspecies, and relegated $N$. inuber (=Dactylopus inuber Schmankevitsch, 1875), N. gracilimana Giesbrecht, 1902, N. wolterecki, N. phlegraea Brehm 1909, and N. chelifer Wilson, 1932, as incertae sedis within the genus. Kunz (1976) described a new subspecies of N. sewelli, N. sewelli husmanni Kunz, 1976 from Bremen (Germany). In his analysis, Kunz (1976) noted that N. sewelli husmanni showed the same armature formula as in $N$. spinipes s. str., $N$. spinipes orientalis, $N$. spinipes armata (not armatus as in Kunz (1976); note that these subspecies were rejected by Wells and Rao 1987, and were not considered in Wells (2007)), N. elegans (T. Scott, 1905), N. fragilis, N. bdellurae (Liddell, 1912), N. sewelli and N. medusae Humes, 1953 (which was considered synonym of $N$. spinipes by Lang (1965)). However, as shown by Sewell (1924), the P1EXP3 of $N$. sewelli is armed with four setae/ spines instead of five elements as in the rest of the above species. Kunz (1976) observed some other differences between his material and Sewell's (1924) description of $N$. sewelli, such as the number of setae on the male P5BENP, relative length of the setae of the male and female P5EXP and shape of the outer dimorphic spine on the male P3ENP3. Sewell (1924) found two males and one female and nothing is said about the intraspecific variability of the species, which for other species seems to be important in subspecies acceptance or rejection (i.e. Wells and Rao 1987). On the other hand, Kunz (1976) found some variability mainly expressed in the armature formula of the female P2ENP2 and P3EXP3, and in the relative length of the setae on the male P5BENP, but the armature formula of the P1EXP remains constant. It seems, therefore, unlikely that the armature formula of P1EXP3 observed by Sewell (1924) in the Indian material is due to intraspecific variability, which, by the way, was not observed by Kunz (1976) in the German specimens. In our opinion, Kunz (1976) erected his new subspecies based more on the differences with some other species, than on the similarities with $N$. sewelli (to which it is implicitly assumed to be more closely related), being the different armature formula of P1EXP and the differences observed by Kunz (1976: 33) enough to separate $N$. sewelli from $N$. sewelli husmanni. It is, therefore, suggested that the latter be granted full species rank as N. husmanni stat. n. Kunz 1976.

At present and taking into account the rejection of all the described subspecies of $N$. spinipes by Wells and Rao (1987), as well as the amendments above, 45 species within the genus are considered as valid. Of these, eight species ( $N$. affinis, $N$. divaricata Chappuis, 1923, N. fallaciosa Klie, 1937, N. hibernica (Brady, 1880), N. lacustris, N. mediterranea Brian, 1928, N. minor Willey, 1930, N. platypus) contain 22 subspecies (Wells 2007). Also, the same species as in Lang (1948) (except for $N$. phlegraea which does not appear in Wells' (2007) list of species) plus N. hyperidis Jakobi, 1956, are regarded as incertae sedis within the genus (Lang 1965, Wells 2007). 
Within the most speciose group (see above), N. australis Soyer, 1974, N. fragilis, $N$. spinipes, $N$. intermedia Pesce, 1983, and $N$. husmanni are unique in the combination of the number of setae/spines of the P2-P4Enp3 and P2-P4EXP3 (4,5,5 and $7,7,7$, respectively) and number of inner setae on the P2-P4Enp1 $(1,1,1)$. Note that Scott (1905) and Monard (1935) described the P4EXP3 with 7 setae/spines. In his description of the male and amendments to the description of the female of $N$. elegans, Gee (2009) showed that the P4EXP3 possesses in fact eight setae/spines (three inner setae, two apical elements and three outer spines), being the distalmost inner seta very slender and relatively short, implicitly suggesting that this seta might have been overlooked in previous descriptions, being $N$. elegans probably more related to the $N$. affinis complex of subspecies and to $N$. hamata Bodin, 1970.

The South African material herein described agrees well with the description of $N$. husmanni by Kunz (1976), to which it seems to be closely related. Unfortunately, Kunz (1976) description lacks the detail needed to make reliable comparisons between species of the genus Nitocra. On the other hand, due to some restrictions regarding the import/export permits of biological material, we were unable to check the specimens of $N$. husmanni deposited by Kunz (1976) in the collection of the Zoologischen Museum Hamburg under catalogue numbers K-30399 and K-30400. The main differences observed between the South African material and $N$. husmanni as described by Kunz (1976), are the number of spinules along the posterior margin of the anal operculum, which is variable in N. spinipes (Wells \& Rao, 1987) (about seven spines in $N$. husmanni, but three in $N$. taylori sp. n.) ; P1EXP:ENP length ratio (exopod shorter than endopod in $N$. husmanni, but exopod nearly as long as endopod in $N$. taylori sp. $\mathrm{n}$.), shape of the outer spine on the male P3ENP3 (curved in $N$. husmanni, but straight in $N$. taylori sp. n.), number of segments of the male antennule (10 segments in $N$. husmanni, but only nine in $N$. taylori sp. n.), relative length of the setae on the male P5BENP (innermost element visibly shorter than the two adjacent outer setae in $N$. husmanni, but innermost element longer in $N$. taylori sp. n.), shape of the male P5EXP (comparatively more elongate in $N$. taylori sp. n.), relative length of the two setae of the male P6, shape of the female P5BENP (broader, less developed and barely reaching the proximal third of the exopod in $N$. taylori sp. n., but well developed, more elongate and reaching far beyond the middle of the exopod in $N$. husmanni).

\section{Ecological remarks}

The nature of freshwater deprivation in the St Lucia Estuary has resulted in a northward gradient of drought effects. While regions in the south have recently been relatively protected from the drought, due to freshwater input from the Mpate and Mfolozi Rivers through the link canal (Whitfield and Taylor 2009), hypersalinity and low water levels have become increasingly more severe towards the north. This profile has fractionated the system into a variety of different habitats in relatively close proximity. 
The first record of $N$. taylori sp. n. in the St Lucia Estuary dates back to 2006, when low densities were collected from Charters Creek, which is situated on the western shore of South Lake. It is possible that this species was present in earlier assessments conducted by Grindley (1976), however, in these assessments, harpacticoid copepods were not identified to species level. The distribution of $N$. taylori sp. n. within the St Lucia Estuary appears to be limited to Catalina Bay and Charters Creek in South Lake and Listers Point in False Bay. No specimens have been recorded from the Mouth or Narrows regions. During closed mouth conditions, False Bay and South Lake are generally characterised by low water levels, high salinities and high turbidities, particularly at Charters Creek and Listers Point. The Mouth and Narrows, on the other hand, are relatively deeper stations with higher water levels and lower salinities.

During this study, $N$. taylori sp. n. individuals were recorded at salinity levels ranging from 9 to 53.7 psu. Many species of Nitocra exhibit wide salinity tolerance, since they occur in a variety of different habitats (rock pools, lagoons and sandy beaches), which naturally experience wide salinity fluctuations (Matias-Peralta et al. 2005). In a study by Matias-Peralta et al. (2005), N. affinis was capable of tolerating salinity levels of 10 to 35 psu. Although this species was capable of surviving a broad range of salinities, reproductive capacity was hindered at the lower part of the salinity range, while levels of 30 to 35 psu were found to provide the best conditions for development. Nitocra spinipes has a slightly wider salinity tolerance, surviving salinity levels ranging from 0.5 to 30 psu (Wulff 1972). In the St Lucia Estuary, N. taylori sp. n. was not found at salinity levels lower than 9 psu. It is, therefore possible that the low salinities prevailing in the lower reaches of the estuary are restricting $N$. taylori sp. n. populations to the lakes region. While a large number of individuals were collected at salinities around 100 psu, these individuals were completely transparent, (having not taken up the stain) and resembled discarded exoskeletons. It is most likely, therefore, that they were not alive at the time of collection. Those individuals that did take up the phloxine stain were only recorded at salinity levels up to $53.7 \mathrm{psu}$.

Matias-Peralta et al. (2005) also found that low light intensities were more favorable for the overall reproduction, population growth and development of $N$. affinis. The high turbidity levels experienced in the lakes of the St Lucia Estuary may, therefore, be favorable to the development of $N$. taylori sp. n. to a certain extent and may also play a role in its distribution within the system. Lastly, water levels in the Mouth and Narrows are deeper than those found in the lakes, which, during closed-mouth conditions, are usually only $-20 \mathrm{~cm}$ deep. It is, therefore, possible that shallow water depths are favoured/ required for the survival of this species.

Species belonging to the genus Nitocra are also known to inhabit a wide range of sediment types (Boxshall and Halsey 2004). Pillay and Perissinotto (2008) classified the sediment of the St Lucia Estuary in 2005. Average values $( \pm$ SE) of sediment particle size (phi) indicate that sediment was generally medium to very fine sand at the mouth $(3.1 \pm 0.5)$, but was finer at Esengeni $(4.08 \pm 0.89)$ where it was classed as very fine sand to coarse silt. Sediments in the South Lake were classed as fine to very fine sand (Charters Creek: $2.48 \pm 0.44$, Catalina Bay: $2.38 \pm 0.48)$. The finest sediments were recorded at Listers Point in False Bay $(6.63 \pm 0.86)$, where they were classed as 
fine silt. This station, therefore, exhibited the highest silt content of $73.38 \pm 6.55 \%$ (Pillay and Perissinotto 2008). Within the St Lucia estuarine lake, N. taylori sp. n. individuals were found in both the South Lake and False Bay which have a variable sediment composition ranging from fine silt to fine sands. Similar sediment is found in other areas of the estuarine lake (i.e. Mouth and Narrows), however, no $N$. taylori sp. $\mathrm{n}$. individuals were recorded here. It is, therefore, more likely that a parameter other than sediment size is restricting their distribution.

Whether the main controlling factor is salinity, turbidity, water level, sediment composition, or a combination of all of them, the distribution of this new potentially endemic species is clearly limited to the lake part of the estuary, an area which is most severely affected by the current freshwater deprivation crisis. It appears that this species cannot tolerate salinity levels above 53.7 psu, however, in the current state of the estuary; salinity levels at Charters Creek and Listers Point often exceed this value. Continued freshwater deprivation would, therefore, further limit the distribution range of this species, but may also threaten its survival within the system. Up until now, research within the St Lucia Estuary has been focused at 5 representative stations, however, further investigations are needed in order to document the full extent of the distribution of $N$. taylori sp. $\mathrm{n}$. within the lakes. Additionally experimental studies on the salinity and temperature tolerance limits of this species would aid in the understanding of the physiological factors which affect its survival.

\section{Acknowledgements}

We are grateful to Holly Nel and Katrin Tirok (School of Life Sciences, University of KwaZulu-Natal) for their help during field work and to the iSimangaliso Wetlands Park Authority and the staff and management of EKZN Wildlife for their support during this project. We are indebted to Mrs Ma. Clara Ramírez Jáuregui (Universidad Nacional Autónoma de México, Instituto de Ciencias del Mar y Limnología, Unidad Académica Mazatlán,) for her help with the search for bibliographic material and to Berenit Mendoza Garfias (Universidad Nacional Autónoma de México, Instituto de Biología) for the scanning microphotographs. Funding for the project was provided by the National Research Foundation (NRF, Pretoria), Marine and Coastal Management (DEA-MCM, Cape Town) and the World Wide Fund (WWF). R. Perissinotto is thanked for providing grant support to NKC and for critically reviewing earlier drafts of the manuscript.

\section{References}

Begg G (1978) The estuaries of natal. Natal Town and Regional Planning Report 41: 1-657. Boeck A (1865) Oversigt over de ved Norges Kyster jagttagne Copepoder henhörende til Calanidernes, Cyclopidernes og Harpactidernes Familier. Forhandlinger i Videnskabsselskabet i Kristiania: 226-282. 
Boxshall GA, Halsey SH (2004) An introduction to copepod diversity. The Ray Society, London, No. 166, 966 pp.

Brady GS (1880) A Monograph of the Free and Semi-parasitic Copepoda of the British Islands. Ray Society, London, Vol. 2, Publication No. 55, 182 pp.

Brehm V (1909) Copepoden aus den phlegräischen Feldern. Zoologischer Anzeiger 34(13/14): 420-423.

Brian A (1928) Descrizione di specie nuove o poco conosciute di copepodi bentonici del mare

Egeo. Bollettino dei Musei di Zoologia e Anatomia Comparata della Universita di Genova 7(18): 1-37.

Carrasco NK, Perissinotto R, Pillay D (2010) Zooplankton of the St. Lucia Estuary during the current drought cycle: a comparison between open- and closed-mouth conditions. Marine Ecology Progress Series 399: 157-171. doi: 10.3354/meps08355

Chappuis PA (1923) Description de deux Harpacticides nouveaux de Transylvanie. Buletinul Societatii de Stiinte din Cluj 2(2): 23-26

Chappuis PA (1930) Copepoda Harpacticoida von der Insel Luzon, Philippinen. Philippine Journal of Science 41: 143-149.

Cyrus DP, Vivier L (2006) Status of the estuarine fish fauna in the St. Lucia Estuarine System, South Africa, after 30 months of mouth closure. African Journal of Aquatic Science 31(1): 71-81. doi: 10.2989/16085910609503873

Daday E (1906) Untersuchungen über die Copepodenfauna von Hinterindien, Sumatra und Java, nebst einem Beitrag zur Copepodenkenntnis der Hawaii-Inseln. (Reise von Dr. Walter Volz). Zoologische Jahrbücher, Abteilung für Systematik, Geographie und Biologie der Thiere 24(3): 175-206.

Daly M, Perissinotto R, Laird M, Dyer D, Todaro A (2012) Description and ecology of a new species of Edwardsia de Quatrefages, 1842 (Anthozoa, Actiniaria) from the St Lucia Estuary, South Africa. Marine Biology Research 8(3): 233-245. doi: 10.1080/17451000.2011.617757

Fielding PJ, Forbes AT, Demetriades NT (1991) Chlorophyll concentrations and suspended particulate loads in St. Lucia, a turbid estuary on the east coast of South Africa. South African Journal of Marine Science 11: 491-498. doi: 10.2989/025776191784287619

Galhano ME (1968) Two new interstitial Ameiridae (Copepoda Harpacticoidea) from Portugal. Publicaçôes do Instituto de Zoologia “Dr. Augusto Nobre” 104: 9-21.

Gee JM (2009) Some new and rare species of Ameiridae (Copepoda: harpacticoida) from the Isles of Scilly, UK. Journal of Natural History 43(45-46): 2809-2851. doi: 10.1080/00222930903373991

Giesbrecht W (1902) Zoologie Copepoden. Résultats du voyage du S.Y. Belgica en 18971898-1899. Rapports scientifiques publiés aux frais du Government Belge, 1-49.

Grindley JR (1976) Zooplankton of St. Lucia. In: Heydorn AEF (Ed.) St. Lucia Scientific Advisory Council Workshop meeting - Charters Creek 15-17 February 1976. Paper 12. Natal Parks Bd, Pietermaritzburg.

Gurney R (1927) Report on the Crustacea: - Copepoda (littoral and semi-parasitic). Zoological results of the Cambridge expedition to the Suez Canal, 1924, no. 33. Transactions of the Zoological Society of London 22:451-577. 
Humes AG (1953) Two new semiparasitic harpacticoid copepods from the coast of New Hampshire. Journal of the Washington Academy of Sciences 43(11): 360-373.

Huys R, Boxshall GA (1991) Copepod evolution. The Ray Society, London, 468 pp.

Jakobi H (1956) Novas espécies de Harpacticoidea (Copepoda Crustacea) provenientes de regiôes de àgua salobra da costa Sao Paulo - Paranà. Dusenia 7(3): 159-171.

Klie W (1937) Ostracoden und Harpacticoiden aus brackigen Gewässern an der bulgarischen Küste des Schwarzen Meeres. Bulletin de l'Institut Royal d'Histoire Naturelle de Sophia 10: $1-42$.

Kunz H (1976) Eine neue Unterart der Gattung Nitocra (Copepoda: Harpacticoidea) aus Norddeutschland. Gewässer und Abwässer 60/61: 27-34.

Lang K (1944) Monographie der Harpacticiden (vorläufige Miiteilung). Almquist \& Wiksells Boktryckeri AB, Uppsala, 1-39.

Lang K (1948) Monographie der Harpacticiden. Vols. 1,2. Sweden: Hakan Ohlsson, Lund, $1682 \mathrm{pp}$.

Lang K (1965) Copepoda Harpacticoidea from the Californian Pacific coast. Sweden: Kungliga Svenska Vetenskapsakademiens Handlingar Fjárde Serien 10: 1-560.

Liddell JA (1912) Nitocrameira bdellurae, nov. gen. et sp., a copepod of the family Canthocamptidae, parasitic in the egg-cases of Bdellura. Journal of the Linnean Society, Zoology 32: 87-94

Matias-Peralta H, Yusoff FMd, Shariff M, Arshad A (2005) Effects of some environmental parameters on the reproduction and development of a tropical marine harpacticoid copepod Nitocra affinis f. californica Lang. Marine Pollution Bulletin 51: 722-728. doi: 10.1016/j. marpolbul.2005.02.047

Monard A (1927) Synopsis universalis generum Harpacticoidarum. Zoologische Jahrbucher. Abteilung für Systematik 54: 139-176.

Monard A (1935) Étude sur la faune des Harpacticoïdes marins de Roscoff. Travaux de la Station Biologique de Roscoff 13: 1-88.

Perissinotto R, Wooldridge TH (1989) Short-term thermal effects of a power-generating plant on zooplankton in the Swartkops Estuary, South Africa. PSZNI Marine Ecology 10: 205-219. doi: 10.1111/j.1439-0485.1989.tb00473.x

Pesce GL (1983) Contributo alla conoscenza degli arpacticoidi delle acque sotterranee della regione pugliese (Crustacea: Copepoda). Thalassia Salentina 13: 61-81.

Pillay D, Perissinotto R (2008) The benthic macrofauna of the St. Lucia Estuary during the 2005 drought year. Estuarine, Coastal and Shelf Science 77: 35-46. doi: 10.1016/j. ecss.2007.09.004

Sars GO (1905) Pacifische Plankton-Crustaceen. (Ergebnisse einer Reise nach dem Pacific. Schauinsland 1896-1897). II. Brackwasser-Crustaceen von den Chatham-Inseln. Zoologische Jahrbücher, Abteilung für Systematik 21(4):371-414

Sars GO (1911) Copepoda Harpacticoida. Parts XXXI \& XXXII. Supplement (continued). An Account of the Crustacea of Norway, with short descriptions and figures of all the species. Bergen Museum, Bergen 5:369-396.

Sars GO (1927) The fresh-water Entomostraca of the Cape Province (Union of South Africa). Part III: Copepoda. Annals of the South African Museum 25(1): 85-149 
Schäfer W (1936) Harpacticoiden aus dem Brackwasser der Insel Hiddensee. Zoologische Jahrbücher Abteilung für Systematik, Ökologie und Geographie der Tiere 68(6): 445-588.

Schmankevitch VI (1875) Nekotoryya rakoobraznyya solyano-ozernykh' i presnykh vod' i otneshenie ikh' k' srede. Some Crustacea of salt and freshwater lakes, and their relation to the surrounding environment. Zapiski Novorossiiskago Obshchestva Estestvoispytatelei (= Mémoires de la Société des Naturalistes de la Nouvelle Russie, Odessa) 3(2):1-391.

Scott T (1905) On some new and rare Crustacea from the Scottish seas. Report of the Fishery Board for Scotland 23(3): 141-153

Sewell RBS (1924) Fauna of the Chilka Lake. Crustacea Copepoda. Memoirs of the Indian Museum, Calcutta 5: 771-851.

Soyer J (1974) Harpacticoides (Crustacés Copépodes) de l'archipel de Kerguelen. 1. Quelques formes mesopsammiques. Bulletin du Muséum National d'Histoire Naturelle, Zoologie, 168: 1169-1223.

Todaro MA, Dal Zotto M, Bownes SJ, Perissinotto R (2011) First records of Gastrotricha from South Africa, with a description of a new species of Halichaetonotus (Chaetonotida: Chaetonotidae). ZooKeys 142: 1-13. doi: 10.3897/zookeys.142.2036

Wells JBJ (2007) An annotated checklist and keys to the species of Copepoda Harpacticoida (Crustacea). Zootaxa 1568: 1-872.

Wells JB, Rao GC (1987) Littoral Harpacticoida (Crustacea: Copepoda) from Andaman and Nicobar Islands. Memoirs of the Zoological Survey of India 16: 1-385.

Whitfield AK, Taylor RH (2009) A review of the importance of freshwater inflow to the future conservation of Lake St. Lucia. Aquatic Conservation 19(7): 838-848. doi: 10.1002/ aqc. 1061

Willey A (1930) Harpacticoid Copepoda from Bermuda. Part I. Annals and Magazine of Natural History, Series 10, 6: 81-114. doi: 10.1080/00222933008673192

Wilson CB (1932) The copepods of the Woods Hole region, Massachusetts. Bulletin of the United States National Museum 158: 1-635

Wulff F (1972) Experimental studies on physiological and behavioural response mechanisms of Nitocra spinipes (Crustacea: Harpacticoidea) from brackish-water rockpools. Marine Biology 13: 325-329. doi: 10.1007/BF00348080 